\title{
Hydrogen Peroxide: A Poor Ligand to Gallium Tetraphenylporphyrin
}

\author{
Antonio G. DiPasquale ${ }^{\dagger}$ and James M. Mayer* \\ Department of Chemistry, Campus Box 351700, \\ University of Washington, Seattle, Washington 98195-1700 \\ mayer@chem.washington.edu
}

\section{Supporting Information}

CAUTION: All metal-peroxide and perchlorate complexes should be prepared and handled in small quantities, stored in an inert atmosphere below $0{ }^{\circ} \mathrm{C}$ and manipulated with Teflon-coated spatulas. $50 \% \mathrm{H}_{2} \mathrm{O}_{2}$ should be handled with care, especially avoiding any contact with transition metals or transition metal salts. $\mathrm{H}_{2} \mathrm{SO}_{5}$ (Caro's acid or 'piranha' solution, from $\mathrm{H}_{2} \mathrm{SO}_{4}+$ aqueous $\mathrm{H}_{2} \mathrm{O}_{2}$ ) is potentially explosive, highly corrosive, strongly oxidizing, and should never come in contact with any organic matter (especially acetone). ${ }^{l}$ All glassware used here was cleaned using a fresh preparation of $\mathrm{H}_{2} \mathrm{SO}_{5}$, rinsed with copious amounts of deionized $\mathrm{H}_{2} \mathrm{O}$, and then flame-dried under vacuum (or oven dried) immediately before use.

\section{Experimental}

General Procedures. All manipulations were performed under an argon or nitrogen atmosphere, using standard high vacuum line or inert atmosphere glove box techniques unless otherwise noted. Protio (Fisher Scientific) and deuterio solvents (Cambridge Isotope) were dried and degassed over $\mathrm{Na} / \mathrm{Ph}_{2} \mathrm{CO}$ (pentane, cyclohexane, heptane, benzene, toluene, $\mathrm{Et}_{2} \mathrm{O}, \mathrm{THF}$ ) or $\mathrm{CaH}_{2}\left(\mathrm{CH}_{2} \mathrm{Cl}_{2}\right)$ and vacuum transferred immediately before use. (TPP) $\mathrm{GaCl}$ was prepared according to the literature. ${ }^{2}$ This compound, and all of the (TPP)Ga compounds derived from it,

\footnotetext{
Current address: Department of Chemistry and Biochemistry, University of California San Diego, Mail Code 0358, 9500 Gilman Drive, La Jolla CA 92093-0358

(1) Edwards, J. O. Chem. Eng. News 1955, 33, 3336.

(2) Coutsolelos, A.; Guilard, R.; Bayeul, D.; Lecomte, C. Polyhedron, 1986, 5, 1157-1164.
} 
typically contained a small amount of (TPP) Ga(OAc) impurity that was visible by ${ }^{1} \mathrm{H}$ NMR. AgOTf, $\mathrm{AgClO}_{4}$ (from Strem), and $\mathrm{C}_{6} \mathrm{Me}_{6}$ (Aldrich) were used as received. $\mathrm{Mg}\left(\mathrm{ClO}_{4}\right)_{2}$ (anhydrous desiccant grade, from Fisher Scientific) was activated under vacuum at $200{ }^{\circ} \mathrm{C}$ overnight and stored in a vacuum desiccator prior to use. Following a related procedure, ${ }^{3}$ $\mathrm{NaOO}^{t} \mathrm{Bu}$ was synthesized by precipitation from equimolar amounts of $\mathrm{HOO}^{t} \mathrm{Bu}(\sim 5.5 \mathrm{M}$ in decane over $4 \AA$ molecular sieves, $>97 \%$ ) and $\mathrm{NaO}^{t} \mathrm{Bu}(>97 \%$, both from Fluka) in THF, filtered, dried in vacuo and stored in a desiccator.

We found it necessary to clean all glassware in contact with $\mathrm{H}_{2} \mathrm{O}_{2}$ with fresh, fuming preparations of $\mathrm{H}_{2} \mathrm{SO}_{5}$, commonly called Caro's acid or 'piranha' solution - SEE CAUTION ABOVE. It was prepared by adding $5 \mathrm{~mL}$ of $98 \% \mathrm{H}_{2} \mathrm{SO}_{4}$ to $5 \mathrm{~mL}$ of $30 \%$ aqueous $\mathrm{H}_{2} \mathrm{O}_{2}{ }^{4}$ Fuming $\mathrm{H}_{2} \mathrm{SO}_{5}$ is quite effective in dissolving inorganic and organic impurities that may be residing on glass surfaces. ${ }^{5}$

NMR spectra were obtained at 298 K (unless otherwise noted) on Bruker Avance DRX499, AV-500 or DMX-750 spectrometers. NMR spectra were obtained using either J. Youngvalved sealable or flame-sealed NMR tubes and are referenced to residual solvent peaks for ${ }^{1} \mathrm{H}$ and ${ }^{13} \mathrm{C}$. Mass spectra were performed in $\mathrm{EI}^{+}$ionization mode using a direct inlet probe on Kratos Profile HV-3 (low resolution) or JEOL HX-110 (high resolution) mass spectrometers. Elemental analyses were performed by Atlantic Microlab (Norcross, GA).

Anhydrous $\mathrm{H}_{2} \mathrm{O}_{2} / \mathrm{CD}_{2} \mathrm{Cl}_{2}$ solutions. In the air, $\mathrm{Mg}\left(\mathrm{ClO}_{4}\right)_{2}(\sim 5 \mathrm{~g})$ was added to a new $25 \mathrm{~g}$ bottle of $\mathrm{CD}_{2} \mathrm{Cl}_{2}$ and the bottle was placed in a freezer at $-4{ }^{\circ} \mathrm{C}$ for $30 \mathrm{~min} .50 \% \mathrm{H}_{2} \mathrm{O}_{2}(\sim 3 \mathrm{~mL})$ was added dropwise over a 10 min period, swirling the bottle gently and placing it back in the freezer between each addition to keep the solution cold. After the complete addition of the $\mathrm{H}_{2} \mathrm{O}_{2}$,

(3) $\mathrm{NaOEt}+\mathrm{HOO}^{t} \mathrm{Bu} \rightarrow \mathrm{NaOO}^{t} \mathrm{Bu}:$ Lobanova, G. N. Visn. L'viv. Politekh. Inst. 1971, 58, 11-14.

(4) Ahrle, H. Angew. Chem. 1910, 22, 1713-1715.

(5) $\mathrm{H}_{2} \mathrm{SO}_{5}$ is commercially sold as Nano-strip ${ }^{\mathrm{TM}}$ by Cyantek Corporation for removal of organic and inorganic impurities from surfaces: http://www.cyantek.com/htm/nano-strip.htm. 


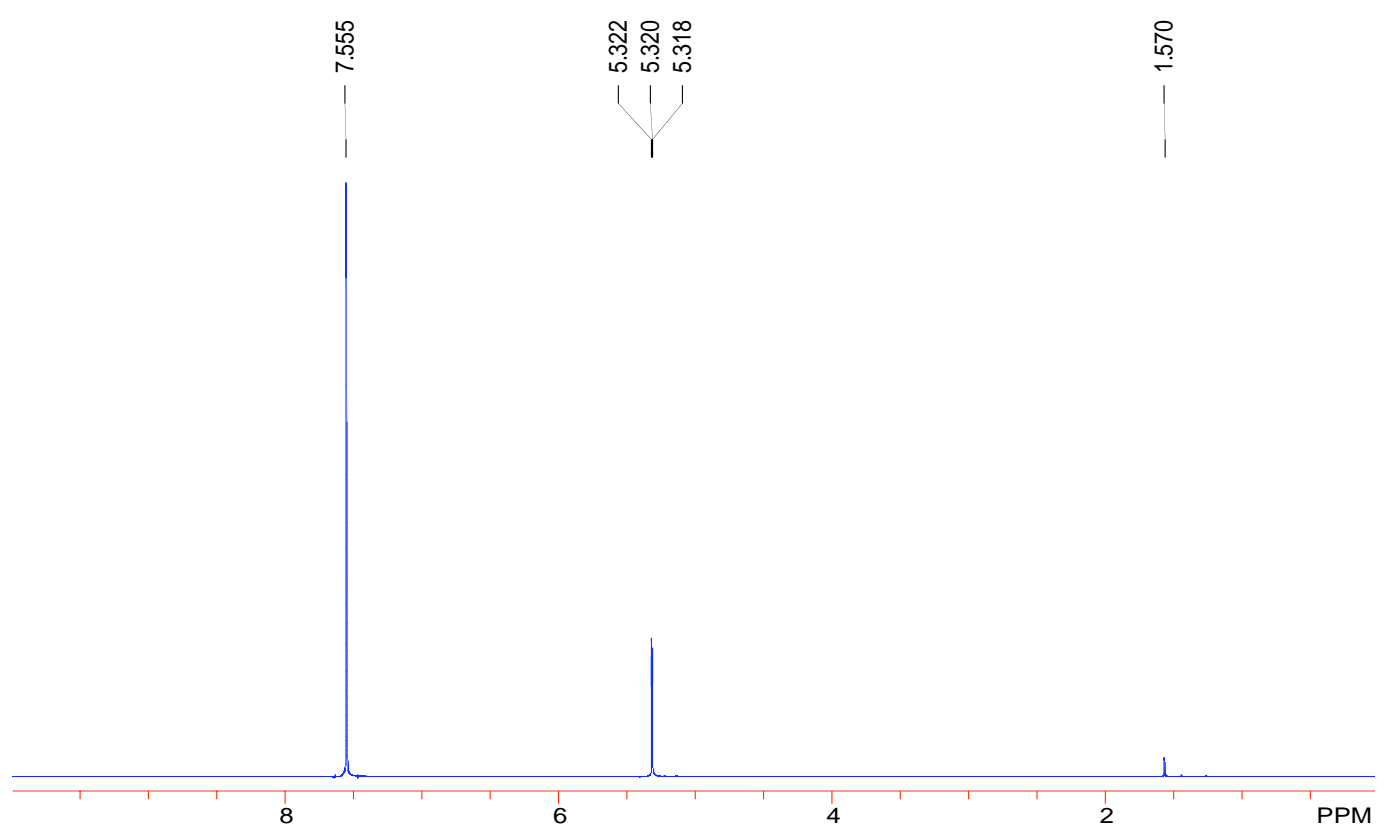

Figure S1. ${ }^{1} \mathrm{H}$ NMR of $\mathrm{H}_{2} \mathrm{O}_{2}(\delta 7.55)$ with a trace amount of $\mathrm{H}_{2} \mathrm{O}$ added $(\delta 1.57)$ in $\mathrm{CD}_{2} \mathrm{Cl}_{2}$.

the solution was allowed to sit over $\mathrm{Mg}\left(\mathrm{ClO}_{4}\right)_{2}$ in a freezer at $-4{ }^{\circ} \mathrm{C}$ overnight before use to allow for complete desiccation. The solution was then stored over the desiccant at $-4{ }^{\circ} \mathrm{C}$ to preserve its integrity. Aliquots were removed using $\mathrm{H}_{2} \mathrm{SO}_{5}$-cleaned glass pipettes (see above). ${ }^{1} \mathrm{H} \mathrm{NMR}$ : $\left(\mathrm{CD}_{2} \mathrm{Cl}_{2}, 25^{\circ} \mathrm{C}\right) 7.55\left(\mathrm{~s}, 2 \mathrm{H}, \mathrm{H}_{2} \mathrm{O}_{2}\right)$ (Figure $\left.\mathrm{S} 1\right)$. The concentration of each preparation was determined using $\mathrm{C}_{6} \mathrm{Me}_{6}$ as an internal standard (solutions were typically $10 \mathrm{mM}$; they have been made at $\left[\mathrm{H}_{2} \mathrm{O}_{2}\right]$ from 1-100 mM). A J. Young-valved NMR tube cleaned using $\mathrm{H}_{2} \mathrm{SO}_{5}$, rinsed with copious amounts of deionized $\mathrm{H}_{2} \mathrm{O}$, and dried in an oven overnight was charged with $0.75 \mathrm{~mL}$ of $\mathrm{H}_{2} \mathrm{O}_{2} / \mathrm{CD}_{2} \mathrm{Cl}_{2}$ solution and monitored by ${ }^{1} \mathrm{H} \mathrm{NMR}$ at $298 \mathrm{~K}$ for 1 month. No loss of $\mathrm{H}_{2} \mathrm{O}_{2}$ nor growth of $\mathrm{H}_{2} \mathrm{O}$ was observed (no $\mathrm{Mg}\left(\mathrm{ClO}_{4}\right)_{2}$ was present in the tube). Addition of $\mathrm{PPh}_{3}$ to this solution quantitatively gave $\mathrm{OPPh}_{3}$ and $\mathrm{H}_{2} \mathrm{O}$ by ${ }^{1} \mathrm{H} \mathrm{NMR} . \mathrm{CD}_{2} \mathrm{Cl}_{2}$ was found to be superior to pentane, cyclohexane, benzene, toluene, $\mathrm{Et}_{2} \mathrm{O}$, THF, and $\mathrm{MeCN}$ in terms of $(i)$ the solubility of $\mathrm{H}_{2} \mathrm{O}_{2}$, (ii) the insolubility of $\mathrm{Mg}\left(\mathrm{ClO}_{4}\right)_{2}$, (iii) the inertness of the solvent towards oxidants, and (iv) the final $\mathrm{H}_{2} \mathrm{O}$ content in the solutions. 
(TPP)GaOTf (1). A $50 \mathrm{~mL}$ round bottom flask was loaded in the glove box with (TPP)GaCl (100 mg, $0.14 \mathrm{mmol})$ and AgOTf (50 mg, $0.19 \mathrm{mmol})$, attached to a swivel frit assembly, removed from the glove box and attached to the vacuum line. $\mathrm{CH}_{2} \mathrm{Cl}_{2}(25 \mathrm{~mL})$ was added and the reaction was stirred for $\sim 12 \mathrm{~h}$. The solvent was removed in vacuo and the product was extracted with $\sim 25 \mathrm{~mL}$ of toluene. The supernatant was then filtered and the product was precipitated with $\sim 10 \mathrm{~mL}$ of pentane to yield 1 as a purple solid (104 mg, 89\% yield; 94\% pure by ${ }^{1} \mathrm{H}$ NMR; contained a small amount of toluene). A single crystal suitable for X-ray diffraction was obtained by vapor diffusion of heptane into a saturated toluene solution over three d at $20{ }^{\circ} \mathrm{C} .{ }^{1} \mathrm{H}$ NMR: $\left(\mathrm{CD}_{2} \mathrm{Cl}_{2}, 25{ }^{\circ} \mathrm{C}\right), 9.22\left(\mathrm{~s}, 8 \mathrm{H}\right.$, pyrrole), $8.24\left(\mathrm{~d}, 8 \mathrm{H},{ }^{3} J_{\mathrm{HH}}=6 \mathrm{~Hz}, o^{-}\right.$ $\mathrm{Ph}), 7.83$ (m, 12H, $m, p$-Ph). ${ }^{13} \mathrm{C}\left\{{ }^{1} \mathrm{H}\right\}$ NMR: $\left(\mathrm{CD}_{2} \mathrm{Cl}_{2}, 25{ }^{\circ} \mathrm{C}\right), 149.6$ (s, $\beta$-pyrrole), 141.3 (s, $i$ Ph), 134.8 (s, $\alpha$-pyrrole), 133.0 (s, $m$-Ph) 128.9 (s, $p$-Ph) 127.6 (s, o-Ph), 121.6 (s, meso), 117.3 $\left(\mathrm{q}, J_{\mathrm{C}-\mathrm{F}}=317 \mathrm{~Hz}, C \mathrm{~F}_{3}\right)$. Anal. Calcd for $\mathrm{C}_{45} \mathrm{H}_{28} \mathrm{~N}_{4} \mathrm{O}_{3} \mathrm{~F}_{3} \mathrm{~S}_{1} \mathrm{Ga}_{1}: \mathrm{C}, 65.00 \% ; \mathrm{H}, 3.39 \%$; N, 6.74\%; Fnd: C, 65.34\%; H, 3.57\%; N, 6.52\%.

(TPP) $\mathrm{GaClO}_{4}$ (2). A $50 \mathrm{~mL}$ round bottom flask was loaded in the glove box with (TPP) $\mathrm{GaCl}$ (100 mg, $0.14 \mathrm{mmol})$ and $\mathrm{AgClO}_{4}(28 \mathrm{mg}, 0.135 \mathrm{mmol})$, attached to a swivel frit assembly, and attached to the vacuum line. $\mathrm{CH}_{2} \mathrm{Cl}_{2}(25 \mathrm{~mL})$ was added and the reaction was stirred for $\sim 12 \mathrm{~h}$. The solution was then filtered and the product precipitated with $\sim 10 \mathrm{~mL}$ of pentane to give $\mathbf{2}$ as a purple solid (79 mg, 72\% yield; $96 \%$ pure by ${ }^{1} \mathrm{H}$ NMR; contains a small amount of (TPP) $\left.\mathrm{GaCl}\right)$. ${ }^{1} \mathrm{H}$ NMR: $\left(\mathrm{CD}_{2} \mathrm{Cl}_{2}, 25{ }^{\circ} \mathrm{C}\right), 9.23$ (s, 8H, pyrrole), 8.24 (br s, $8 \mathrm{H}, o-\mathrm{Ph}$ ), 7.83 (br s, 12H, $m, p$-Ph). ${ }^{13} \mathrm{C}\left\{{ }^{1} \mathrm{H}\right\}$ NMR: $\left(\mathrm{CD}_{2} \mathrm{Cl}_{2}, 25{ }^{\circ} \mathrm{C}\right), 149.8$ (br s, $\beta$-pyrrole), 141.3 (br s, $i$-Ph), 134.8 (br s, $\alpha$ pyrrole), $133.1(\mathrm{~s}, m-\mathrm{Ph}) 128.9(\mathrm{~s}, p-\mathrm{Ph}) 127.6(\mathrm{~s}, o-\mathrm{Ph}), 121.7$ (s, meso). Anal. Calcd for $\mathrm{C}_{44} \mathrm{H}_{28} \mathrm{~N}_{4} \mathrm{O}_{4} \mathrm{Cl}_{1} \mathrm{Ga}_{1}$ : C, 67.59\%; H, 3.61\%; N, 7.17\%; Fnd: C, 67.26\%; H, 3.51\%; N, 6.94\%. 
(TPP)GaO ${ }^{t}$ Bu. (TPP) GaCl (100 mg, $\left.0.14 \mathrm{mmol}\right)$ and $\mathrm{NaO}^{t} \mathrm{Bu}(27 \mathrm{mg}, 0.28 \mathrm{mmol})$ were dissolved in $25 \mathrm{~mL}$ of THF and the resulting solution was stirred at room temperature for $2 \mathrm{~h}$. The THF was then removed in vacuo and the remaining solid was washed twice with pentane in air. In air, the product was extracted using $3 \times 25 \mathrm{~mL}$ aliquots of $\mathrm{CH}_{2} \mathrm{Cl}_{2}$, and then filtered through a plug of Celite ${ }^{\circledR}$. The solvent was removed in vacuo, yielding (TPP) $\mathrm{GaO}^{t} \mathrm{Bu}(83 \mathrm{mg}$, $79 \%$ yield; $96 \%$ pure by ${ }^{1} \mathrm{H}$ NMR). ${ }^{1} \mathrm{H}$ NMR: $\left(\mathrm{CD}_{2} \mathrm{Cl}_{2}, 25{ }^{\circ} \mathrm{C}\right), 9.06$ (s, 8H, pyrrole), 8.20 (br s, $8 \mathrm{H}, o-\mathrm{Ph}), 7.79(\mathrm{~m}, 12 \mathrm{H}, m, p-\mathrm{Ph}),-2.18\left(\mathrm{~s}, 9 \mathrm{H}, \mathrm{Ga}-\mathrm{OC}\left(\mathrm{CH}_{3}\right)_{3}\right) \cdot{ }^{13} \mathrm{C}\left\{{ }^{1} \mathrm{H}\right\} \mathrm{NMR}:\left(\mathrm{CD}_{2} \mathrm{Cl}_{2}, 25\right.$ ${ }^{\circ} \mathrm{C}$ ), 149.5 (s, $\beta$-pyrrole), 142.1 (s, $i$-Ph), 134.8 (br s, $\alpha$-pyrrole), 132.6 (s, $m$-Ph) 128.5 (s, $p$-Ph) $127.4(\mathrm{~s}, o-\mathrm{Ph}), 121.0$ (s, meso), $\left.63.8(\mathrm{~s}, \mathrm{Ga}-\mathrm{OCMe})_{3}\right), 29.6\left(\mathrm{~s}, \mathrm{Ga}-\mathrm{OC}\left(\mathrm{CH}_{3}\right)_{3}\right)$. Anal. Calcd for $\mathrm{C}_{44} \mathrm{H}_{29} \mathrm{~N}_{4} \mathrm{O}_{1} \mathrm{Ga}_{1}$ : C, 76.30\%; H, 4.94\%; N, 7.42\%; Fnd: C, 76.19\%; H, 5.05\%; N, 7.71\%.

(TPP)GaOH (3). (TPP) $\mathrm{GaO}^{t} \mathrm{Bu}(100 \mathrm{mg}, 0.13 \mathrm{mmol})$ was dissolved in $50 \mathrm{~mL}$ of THF with 1 $\mathrm{mL}$ deionized $\mathrm{H}_{2} \mathrm{O}$ added and stirred overnight. The THF was removed in vacuo and the product was extracted with hot toluene. The solvent was concentrated down to $\sim 10 \mathrm{~mL}$ and the product was precipitated with heptane, yielding 3 (72 mg, 79\% isolated yield; 94\% pure by ${ }^{1} \mathrm{H}$ NMR). $\mathrm{X}$-ray quality crystals were obtained by dissolving 3 in $\mathrm{CD}_{2} \mathrm{Cl}_{2}$ in an $\mathrm{NMR}$ tube and allowing it to sit for $3 \mathrm{~d}$ tightly capped. ${ }^{1} \mathrm{H} \mathrm{NMR}$ : $\left(\mathrm{CD}_{2} \mathrm{Cl}_{2}, 25{ }^{\circ} \mathrm{C}\right), 9.09$ (s, $8 \mathrm{H}$, pyrrole), 8.24 (br d, $8 \mathrm{H}, o-$ $\mathrm{Ph}), 7.80$ (m, 12H, m,p-Ph), -6.63 (br s, 1H, Ga-OH). ${ }^{13} \mathrm{C}\left\{{ }^{1} \mathrm{H}\right\} \mathrm{NMR}:\left(\mathrm{CD}_{2} \mathrm{Cl}_{2}, 25{ }^{\circ} \mathrm{C}\right), 149.6$ (s, $\beta$-pyrrole), 142.1 (s, $i$-Ph), 134.9 (br s, $\alpha$-pyrrole), 132.6 (s, $m$-Ph) 128.6 (s, $p$-Ph) 127.4 (s, o-Ph), 121.0 (s, meso). Anal. Calcd for $\mathrm{C}_{44} \mathrm{H}_{29} \mathrm{~N}_{4} \mathrm{O}_{1} \mathrm{Ga}_{1}$ : C, 75.55\%; H, 4.18\%; N, 8.01\%; Fnd: C, $75.51 \% ; \mathrm{H}, 4.19 \% ; \mathrm{N}, 7.99 \%$.

(TPP) $\mathrm{GaCH}_{3}$ (4). (TPP) $\mathrm{GaCl}(100 \mathrm{mg}, 0.14 \mathrm{mmol})$ and $\mathrm{Et}_{2} \mathrm{O}(25 \mathrm{~mL})$ were added to a $50 \mathrm{~mL}$, 2-neck round bottom flask, with a septum closing the outer neck, attached to a swivel-frit filtration apparatus. At $-20^{\circ} \mathrm{C}, 125 \mu \mathrm{L}$ of a $1.6 \mathrm{M}$ MeLi solution $(0.20 \mathrm{mmol})$ was added to the slurry dropwise over a few min. The reaction was allowed to warm to room temperature, turning from a purple slurry to a green solution, and was stirred for $1 \mathrm{~h}$. The solvent was removed in 
vacuo, the product extracted with $25 \mathrm{~mL}$ of $\mathrm{CH}_{2} \mathrm{Cl}_{2}$, and the resulting solution was filtered. Removal of the solvent in vacuo afforded 4 as a royal-blue solid (64 mg, 66\% isolated yield; $96 \%$ pure by ${ }^{1} \mathrm{H}$ NMR). A single crystal suitable for X-ray diffraction was obtained by vapor diffusion of pentane into a saturated $\mathrm{CH}_{2} \mathrm{Cl}_{2}$ solution over two d at $20{ }^{\circ} \mathrm{C} .{ }^{1} \mathrm{H}$ NMR: $\left(\mathrm{CD}_{2} \mathrm{Cl}_{2}, 25\right.$ $\left.{ }^{\circ} \mathrm{C}\right), 9.02$ (s, 8H, pyrrole), 8.22 (br s, $\left.8 \mathrm{H}, o-\mathrm{Ph}\right), 7.78$ (m, 12H, $\left.m, p-\mathrm{Ph}\right),-6.26\left(\mathrm{~s}, 3 \mathrm{H}, \mathrm{Ga}-\mathrm{CH}_{3}\right)$. ${ }^{13} \mathrm{C}\left\{{ }^{1} \mathrm{H}\right\}$ NMR: $\left(\mathrm{CD}_{2} \mathrm{Cl}_{2}, 25{ }^{\circ} \mathrm{C}\right), 146.3$ (s, $\beta$-pyrrole), 139.9 (s, $i$-Ph), 139.2 (s, $\alpha$-pyrrole), 131.2 (s, $m$-Ph) $129.8\left(\mathrm{~s}, p\right.$-Ph) $129.1(\mathrm{~s}, o-\mathrm{Ph}), 123.6$ (s, meso), 33.7 (br s, $\mathrm{Ga}-\mathrm{CH}_{3}$ ). Anal. Calcd for $\mathrm{C}_{44} \mathrm{H}_{29} \mathrm{~N}_{4} \mathrm{O}_{1} \mathrm{Ga}_{1}$ : C, 77.49\%; H, 4.48\%; N, 8.03\%; Fnd: C, 77.32\%; H, 4.49\%; N, 7.88\%.

[(TPP) Ga $\left(\mathrm{OH}_{2}\right) \mathrm{ClO}_{4}(\mathbf{5})$ was generated in the same manner as $[(\mathrm{TPP}) \mathrm{Ga}] \mathrm{ClO}_{4}$ except that hydrated silver perchlorate $\mathrm{Ag}\left(\mathrm{H}_{2} \mathrm{O}\right)_{x} \mathrm{ClO}_{4}$ (Aldrich and/or Strem) was used in place of anhydrous $\mathrm{AgClO}_{4} \cdot{ }^{1} \mathrm{H}$ NMR $\left(\mathrm{CD}_{2} \mathrm{Cl}_{2}\right): 8.75$ (s, 8H, pyrrole), 7.95 (m, 8H, o-Ph), 7.65 (m, 12H, $m, p-\mathrm{Ph}),-14.2\left(\mathrm{~s}, 2 \mathrm{H}, \mathrm{H}_{2} \mathrm{O}\right)$. This material is not soluble enough to obtain a ${ }^{13} \mathrm{C}\left\{{ }^{1} \mathrm{H}\right\} \mathrm{NMR}$ spectrum. Dissolving (TPP) $\mathrm{GaClO}_{4}$ in wet $\mathrm{CH}_{2} \mathrm{Cl}_{2}$ deposited the X-ray quality single crystals of $\left[(\mathrm{TPP}) \mathrm{Ga}\left(\mathrm{OH}_{2}\right)_{2}\right] \mathrm{ClO}_{4}$ on the side of the vial over a 24 hour period.

Reactions with anhydrous $\mathrm{H}_{2} \mathrm{O}_{2}$ were done in $\mathrm{H}_{2} \mathrm{SO}_{5}$-washed NMR tubes (see above) at ambient temperatures. Addition of 4 to $\mathrm{H}_{2} \mathrm{O}_{2} / \mathrm{CD}_{2} \mathrm{Cl}_{2}$ solutions at room temperature did not cause any change in the ${ }^{1} \mathrm{H}$ NMR spectra: the $\mathrm{H}_{2} \mathrm{O}_{2}$ peak remained unchanged both in chemical shift $(\delta 7.55)$ and in integration value (versus an internal standard) in the presence of 4 over at least 7 days. Addition of $\mathrm{PPh}_{3}$ to such solutions of $\mathbf{4}$ and $\mathrm{H}_{2} \mathrm{O}_{2}$ after a week formed $\mathrm{OPPh}_{3}$ and $\mathrm{H}_{2} \mathrm{O}$ in $98 \%$ yield (relative to the initial $\mathrm{H}_{2} \mathrm{O}_{2}$ concentration) and left 4 unchanged. Similar experiments between 4 and $\mathrm{H}_{2} \mathrm{O}_{2}$ at higher temperatures (up to $60^{\circ} \mathrm{C}$ ) only resulted in the quantitative decomposition of $\mathrm{H}_{2} \mathrm{O}_{2}$ to $\mathrm{H}_{2} \mathrm{O}$ with no change seen in $\mathbf{4}$, indicating that 4 does not react with $\mathrm{H}_{2} \mathrm{O}$ either (even at elevated temperatures). Complex 4 reacts with triflic acid (HOTf) to give 1. The addition of $\mathbf{1}$ to $\mathrm{H}_{2} \mathrm{O}_{2} / \mathrm{CD}_{2} \mathrm{Cl}_{2}$ was very similar, with no reaction observed by ${ }^{1} \mathrm{H}$ $\mathrm{NMR}$ and addition of $\mathrm{PPh}_{3}$ yielding quantitative formation of $\mathrm{OPPh}_{3}$ and $\mathrm{H}_{2} \mathrm{O}$ by ${ }^{1} \mathrm{H} \mathrm{NMR}$ 
Attempts to crystallize 5 in the presence of $\mathrm{H}_{2} \mathrm{O}_{2}$ only gave crystals of the hydroxide complex 3 .

Dropwise addition of $\mathrm{H}_{2} \mathrm{O}_{2} / \mathrm{CD}_{2} \mathrm{Cl}_{2}$ solution ( $2 \mu \mathrm{L} /$ drop) to solutions of purified 2 showed slight changes in the ${ }^{1} \mathrm{H}$ NMR spectra (Figure S2). Upon successive additions of $\mathrm{H}_{2} \mathrm{O}_{2} / \mathrm{CD}_{2} \mathrm{Cl}_{2}$ solution, a noticeable broadening of the resonances for $\mathbf{2}$ occurs, followed by a sharpening of those same resonances with no change in their chemical shift. Addition of $\mathrm{PPh}_{3}$ to such solutions gives a quantitative yield of $\mathrm{OPPh}_{3}$ based on the amount of $\mathrm{H}_{2} \mathrm{O}_{2}$ added, and $\mathbf{5}$ forms from the $\mathrm{H}_{2} \mathrm{O}$ generated in this reaction. ( $\mathrm{PPh}_{3}$ is converted to $\mathrm{OPPh}_{3}$ by $\mathrm{H}_{2} \mathrm{O}_{2} / \mathrm{CD}_{2} \mathrm{Cl}_{2}$ solutions even in the absence of gallium complexes). Reactions of $2+\mathrm{H}_{2} \mathrm{O}_{2} / \mathrm{CD}_{2} \mathrm{Cl}_{2}$ with cyclohexene, norbornene, and trans-stilbene did not yield any oxidized olefins by ${ }^{1} \mathrm{H}$ NMR or GC-MS.

The aquo complex 5 was generated in situ by dissolving 2 in $\mathrm{CD}_{2} \mathrm{Cl}_{2}$ saturated with $\mathrm{H}_{2} \mathrm{O}$, yielding a mixture of $\mathbf{2}$ and $\mathbf{5}$ by ${ }^{1} \mathrm{H}$ NMR (Figure S3, bottom); some $\mathbf{5}$ also precipitated. $\mathrm{H}_{2} \mathrm{O}_{2} / \mathrm{CD}_{2} \mathrm{Cl}_{2}$ solution, $\sim 0.25 \mathrm{~mL}$, was then added to this tube and the spectrum was retaken (Figure S3, top). Using the peaks due to the inert (TPP)GaOAc impurity as an internal ${ }^{1} \mathrm{H}$ NMR integration standard (it is completely soluble in $\mathrm{CD}_{2} \mathrm{Cl}_{2}$ ), the concentration of $\mathbf{5}$ in solution actually increases slightly, not decreases, upon addition of $\mathrm{H}_{2} \mathrm{O}_{2} / \mathrm{CD}_{2} \mathrm{Cl}_{2}$ solution. This may be a result of the greater solubility of 5 in the presence of $\mathrm{H}_{2} \mathrm{O}_{2}$. No other changes in the ${ }^{1} \mathrm{H}$ NMR spectra are observed, other than a minute shift downfield of the axial $\mathrm{H}_{2} \mathrm{O}$ resonance of $5(<0.02$ ppm). 


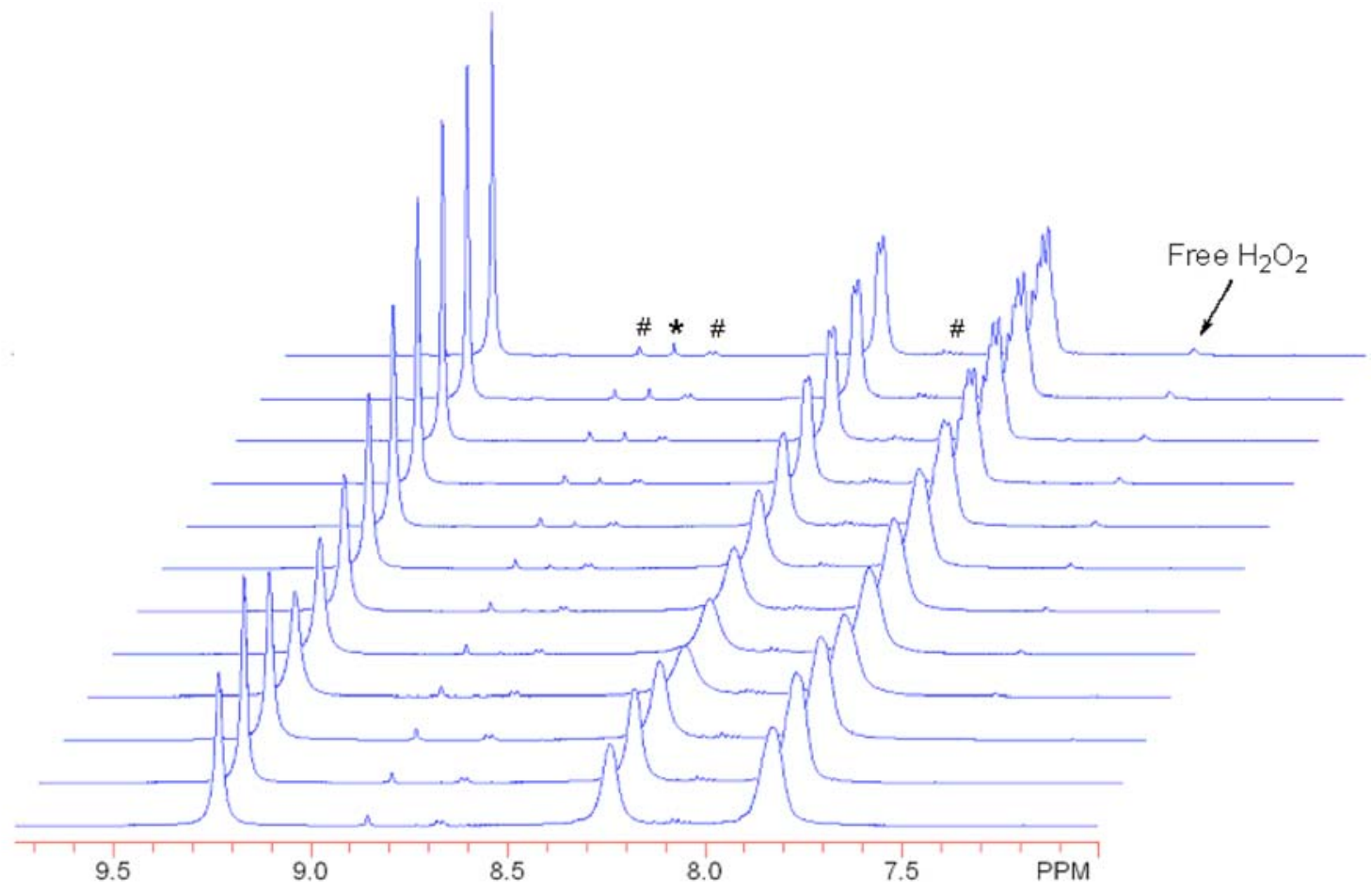

Figure S2. ${ }^{1} \mathrm{H}$ NMR titration, adding $\mathrm{H}_{2} \mathrm{O}_{2} / \mathrm{CD}_{2} \mathrm{Cl}_{2}$ (bottom is zero added) into a dry $\mathrm{CD}_{2} \mathrm{Cl}_{2}$ solution of $\mathbf{2}$ (slices offset for clarity; major peaks are due to $\mathbf{2}$; \# = (TPP)GaOAc impurity; $* \mathbf{*}$ ).
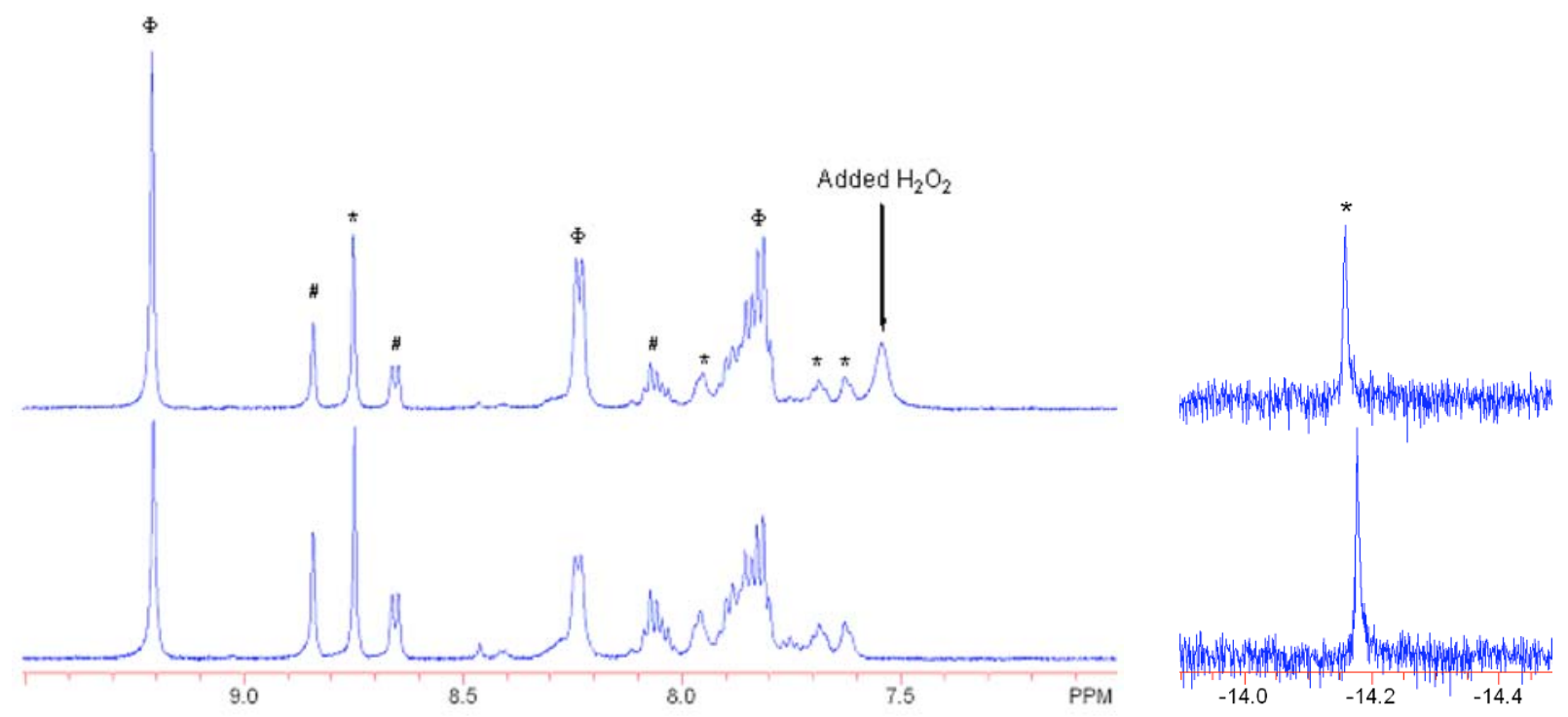

Figure S3. ${ }^{1} \mathrm{H}$ NMR of 2 using wet $\mathrm{CD}_{2} \mathrm{Cl}_{2}$ before (bottom) and after (top) addition of anhydrous $\mathrm{H}_{2} \mathrm{O}_{2} / \mathrm{CD}_{2} \mathrm{Cl}_{2}$ solution $(\Phi=\mathbf{2}$; \# = (TPP)GaOAc impurity; * = 5). 
X-ray crystallographic studies of $1,3,4$, and 5. Crystals were mounted on a glass capillary with oil at $-143{ }^{\circ} \mathrm{C}$. Intensity data were collected on an Enraf-Nonius KappaCCD diffractometer equipped with a fine focus Mo-target X-ray tube. The data were integrated and scaled using hkl2000..$^{6}$ This program applies a multiplicative correction factor $(S)$ to the observed intensities $(I)$ : $S=\left(e^{-2 B\left(\sin ^{2} \theta\right) / \lambda^{2}}\right) /$ scale. $S$ is calculated from the scale and the $B$ factor, which is determined for each frame and is then applied to $I$ to give the corrected intensity $\left(I_{\text {corr }}\right)$. Solutions by direct methods (SIR 97) produced complete heavy atom-phasing models. ${ }^{7}$ In each structure, all hydrogen atoms were placed using a riding model and all non-hydrogen atoms were refined anisotropically by full-matrix least squares (SHELXL-97). ${ }^{8}$

(6) Otinowski, Z; Minor, W. Processing of X-ray Diffraction Data Collected in Oscillation Mode. In Methods in Enzymology; Carter, C. W., Jr., Sweet, R. M., Eds.; Academic Press: New York, 1996; pp 307-326.

(7) Altomare, A.; Cascarano, G.; Giacovazzo, C.; Burla, M. C.; Polidori, G.; Camalli, M. J. Appl. Cryst. 1994, 27, 435-442.

(8) Sheldrick, G. M. SHELXL-97: Program for the Refinement of Crystal Structures; University of Göttingen: Göttingen, Germany, 1997. 